\title{
Aluminosugilite, $\mathrm{KNa}_{2} \mathrm{Al}_{2} \mathrm{Li}_{3} \mathrm{Si}_{12} \mathrm{O}_{30}$, an $\mathrm{Al}$ analogue of sugilite, from the Cerchiara mine, Liguria, Italy
}

\author{
Mariko Nagashima $^{1}$, Chihiro Fukuda ${ }^{2}$, Takashi Matsumoto ${ }^{3}$, Teruyoshi Imaoka ${ }^{1}$, Gianluca Odicino ${ }^{4}$, \\ and Gianluca Armellino 5 \\ ${ }^{1}$ Graduate school of Sciences and Technology for Innovation, Yamaguchi University, \\ Yoshida 1677-1, Yamaguchi 753-8512, Japan \\ ${ }^{2}$ Gem Research Japan Inc., Nagahorido BLDG 5F 1-3-10, Higashi-Shinsaibashi, \\ Chuo-ku, Osaka 542-0083, Japan \\ ${ }^{3}$ Application Laboratories, Rigaku Corporation, 3-9-12 Matsubara-cho, Akishima, Tokyo 196-8666, Japan \\ ${ }^{4}$ Associazione Micro-mineralogica Italiana, via Fasceto 15, 16032 Camogli, Genoa, Italy \\ ${ }^{5}$ Associazione Micro-mineralogica Italiana, via Piani del Monastero 17, 17017 Millesimo, Savona, Italy
}

Correspondence: Mariko Nagashima (nagashim@yamaguchi-u.ac.jp)

Received: 28 June 2019 - Accepted: 16 September 2019 - Published: 16 January 2020

\begin{abstract}
Aluminosugilite (IMA2018-142), ideal formula $\mathrm{KNa}_{2} \mathrm{Al}_{2} \mathrm{Li}_{3} \mathrm{Si}_{12} \mathrm{O}_{30}$, is a new mineral that was found in the interstices in manganiferous metacherts from the Cerchiara mine, Liguria, Italy. Aluminosugilite is an Al analogue of sugilite belonging to the milarite group. It occurs as aggregates of small prismatic and/or granular crystals up to $1 \mathrm{~mm}$ in length, and it is pinkish-purple with a pale purple to white streak and a vitreous lustre. It has a Mohs hardness of 6-6.5. Its cleavage is indistinct, poor on (0001). Measured and calculated densities are $D_{\text {meas. }}=2.71-2.72 \mathrm{~g} \mathrm{~cm}^{-3}$ and $D_{\text {calc. }}=2.73 \mathrm{~g} \mathrm{~cm}^{-3}$, respectively. Aluminosugilite is optically uniaxial (-), with $\omega=1.577-1.586$ and $\varepsilon=1.575-1.585$, with a weak pleochroism. The magnetic susceptibility is lower than that for sugilite. Aluminosugilite is insoluble in $\mathrm{HCl}, \mathrm{HNO}_{3}$ and $\mathrm{H}_{2} \mathrm{SO}_{4}$, like sugilite. The empirical formula of aluminosugilite calculated on the basis of $\mathrm{O}=30$ from the result obtained by electron microprobe analysis and laser-induced breakdown spectroscopy is $\mathrm{K}_{0.99} \mathrm{Na}_{1.99}\left(\mathrm{Al}_{1.38} \mathrm{Mn}_{0.31}^{3+} \mathrm{Fe}_{0.24}^{3+} \mathrm{Ti}_{0.05} \mathrm{Mg}_{0.01}\right)_{\Sigma 1.99} \mathrm{Li}_{3.06} \mathrm{Si}_{11.99} \mathrm{O}_{30}$. Structure refinement converged to $R_{1}=2.17 \%$. Its space group is hexagonal $P 6 / m c c$, with unit-cell parameters $a=9.9830(4) \AA, c=13.9667(5) \AA$ and $V=1205.45(7) \AA^{3}$. Based on the refined site occupancies, the ideal structural formula of aluminosugilite is ${ }^{C} \mathrm{~K}^{B} \mathrm{Na}_{2}^{A} \mathrm{Al}_{2}^{T 2} \mathrm{Li}_{3}^{T}{ }^{1} \mathrm{Si}_{12} \mathrm{O}_{30}$. The variation of the $A-\mathrm{O} 3$ distance is governed by the cationic substitution at the $A$ site. The $a$ and $c$ dimensions of aluminosugilite are shorter than those of sugilite due to Al substitution for $\mathrm{Fe}^{3+}$ at the $A$ site.
\end{abstract}

\section{Introduction}

Aluminosugilite (IMA2018-142), ideal formula $\mathrm{KNa}_{2} \mathrm{Al}_{2} \mathrm{Li}_{3} \mathrm{Si}_{12} \mathrm{O}_{30}$, was found in manganiferous metacherts from the Cerchiara mine, Liguria, Italy. To the best of our knowledge, this is the ninth new mineral species discovered from this locality. For instance, one of the new species from this locality was the Li-bearing mineral, balestraite $\mathrm{KLi}_{2} \mathrm{~V}^{5+} \mathrm{Si}_{4} \mathrm{O}_{10} \mathrm{O}_{2}$ (Lepore et al., 2015). Aluminosugilite is an $\mathrm{Al}$ analogue of sugilite, $\mathrm{KNa}_{2} \mathrm{Fe}_{2}^{3+} \mathrm{Li}_{3} \mathrm{Si}_{12} \mathrm{O}_{30}$ (Murakami et al., 1976; Kato et al., 1976; Armbruster and Oberhänsli, 1988) belonging to the milarite group, which is also known as the osumilite group (synonymous). Milarite-group minerals are chemically very diverse. More than 20 independent species are currently known (see Table 2 in Gagné and Hawthorne, 2016; also Table S1 in the Supplement linked to this article and freely available at https://pubs.geoscienceworld.org/eurjmin, last access: 30 October 2019). Its general formula is represented as ${ }^{\mathrm{VI}} A_{2}^{\mathrm{IX}} B_{2}^{\mathrm{XII}} C^{\mathrm{IV}}(T 2)_{3}^{\mathrm{IV}}(T 1)_{12} \mathrm{O}_{30}$ (e.g. Forbes et al., 1972), where $A=\mathrm{Al}, \mathrm{Fe}^{3+}, \mathrm{Fe}^{2+}, \mathrm{Mg}, \mathrm{Zr}, \mathrm{Sn}, \mathrm{Y}, \mathrm{Ca}, \mathrm{Sc}$ and others; $B=\mathrm{K}, \mathrm{Na}, \square$ (vacant), $\mathrm{H}_{2} \mathrm{O} ; C=\mathrm{K}, \mathrm{Na}, \mathrm{Ba}$, (vacant); $T 1=\mathrm{Si}, \mathrm{Al} ; T 2=\mathrm{Li}, \mathrm{Be}, \mathrm{B}, \mathrm{Mg}, \mathrm{Al}, \mathrm{Si}, \mathrm{Zn}, \mathrm{Fe}^{2+}$, 
$\mathrm{Mn}^{2+}$. Milarite-group minerals are double-ring silicates with maximum topological symmetry of space group $P 6 / m c c$. However, cation or vacancy order may lead to symmetry lowering, for example armenite (Armbruster and Czank, 1992; Armbruster, 1999) and roedderite (Armbruster, 1989). The crystal structure is characterized by two $T 1_{6} \mathrm{O}_{18}$ rings of tetrahedra forming a $T 1_{12} \mathrm{O}_{30}$ double-ring through linkages of their apical vertices. Heterovalent (coupled) substitutions among the $A, B$ and $T 2$ sites are common in this group, leading to the observed chemical variability.

The mineral aluminosugilite is named after sugilite, which has $\mathrm{Fe}^{3+}$-dominant composition at the $A$ site. Thus, "alumino-" is added as prefix in accordance with the guideline on mineral nomenclature of the IMA Commission (Nickel and Grice, 1998), especially on the use of prefixes and suffixes (Hey and Gottardi, 1980). Sugilite was named by Murakami et al. (1976) in honour of late Ken-ichi Sugi (1901-1948) of the Kyushu Imperial University, who first found the occurrence of sugilite on the Iwagi Islet, Ehime, Japan, representing the type locality of sugilite. The type specimen of aluminosugilite will be deposited in the National Museum of Nature and Science, Tsukuba, Japan, under the specimen number NSM-MF-16503 (holotype). In the present study, the new mineral from the Cerchiara mine was examined using electron microprobe analysis (EMPA), laserinduced breakdown spectroscopy (LIBS) and X-ray singlecrystal diffraction methods. In addition, sugilite from the Iwagi Islet was also studied as a reference material for further understanding.

\section{Occurrence}

Aluminosugilite was found in the interstices in manganiferous metacherts from the Cerchiara mine, Faggiona, Borghetto Vara-Pignone, La Spezia, Liguria, Italy $\left(44.116^{\circ} \mathrm{N}, 9.420^{\circ} \mathrm{E}\right)$. Mineral assemblages, mineralization of Mn ores and ore genesis of the Cerchiara mine were studied by Lucchetti et al. (1988) and Cabella et al. (1998). The Cerchiara mine exploited braunite and hematite until 1945. It is a manganese and iron ore deposit hosted in Jurassic ophiolitic metacherts consisting of braunite with minor quartz layers interbedded with hematite and quartz bands formed at condition of prehnite-pumpellyite facies (Lucchetti et al., 1988; Cabella et al., 1998). The ore was produced by precipitation from submarine hydrothermal vents and reworked by turbiditic resedimentation (Cabella et al., 1998). According to Lucchetti et al. (1988), the two very common assemblages of ores are braunite + quartz and hematite + quartz, and mineral assemblages are characterized by Na-clinopyroxene, alkali and sodic-calcic amphiboles, andradite, piemontite, pectolite, ganophyllite, and carbonates. In particular, the compositional variety of Na-clinopyroxene is distinct, which varies from pure aegirine to aegirine-augite with variable $\mathrm{Mg}, \mathrm{Mn}$ and $\mathrm{Ca}$ contents.
The presence of hematite and braunite as main constituents of the ore body suggests highly oxidizing conditions. The mineralization at the Cerchiara mine experienced hydrothermal metasomatism induced by diffuse interaction with alkalirich fluids, which produced peculiar mineral assemblages enriched in $\mathrm{Na}, \mathrm{K}$ and $\mathrm{Li}$ and provided also appreciable amounts of $\mathrm{Ba}, \mathrm{Sr}, \mathrm{Ca}$ and $\mathrm{Cu}$ (e.g. Kolitsch et al., 2018). Aluminosugilite is one of the representative $(\mathrm{Na}, \mathrm{K}, \mathrm{Li})$-rich minerals formed under alkali-rich and oxidized conditions.

The sugilite-type mineral from the Cerchiara mine was first reported by Cabella et al. (1990). According to their study, it occurs in very compact aggregates filling veins in the metacherts, and its aggregate commonly contains fibrous pectolite. Chemical heterogeneity of sugilite due to $\mathrm{Mn}^{3+}-$ $\mathrm{Al}$ substitution was reported in their study. The $\mathrm{Mn}_{2} \mathrm{O}_{3}$ and $\mathrm{Al}_{2} \mathrm{O}_{3}$ contents in sugilite range between $1.5 \mathrm{wt} \%-6.5 \mathrm{wt} \%$ and $5.8 \mathrm{wt} \%-9.7 \mathrm{wt} \%$, respectively (Table 1 in Cabella et al., 1990). In their study, it was presented as Al-rich, Fe-poor manganoan sugilite. They confirmed the significant amount of lithium in sugilite by means of atomic absorption determination; however, the difficulty to remove very fine inclusions of fibrous pectolite did not allow them to provide a reliable composition. On the other hand, in our specimens collected by one of the authors (Gianluca Armellino) in 1997, aluminosugilite was closely associated with quartz and $\mathrm{K}$-feldspar, but close association with pectolite was not observed. Sugilite at Cerchiara was originally described (Lucchetti et al., 1988) as forming big zoned purple veins of some centimetres height, sometimes interleaved with light-blue richterite veins and braunite, but several other occurrences followed in the last 30 years in the abandoned dumps and in the bed of Redarena Creek, where sugilite may form prismatic euhedral purple crystals up to $3 \mathrm{~mm}$ long.

\section{Appearance, physical and optical properties}

Aluminosugilite commonly occurs as aggregates of small prismatic and/or granular crystals up to $1 \mathrm{~mm}$ in length (Fig. 1). Although the Fe analogue of sugilite from the Iwagi Islet is known to show brownish-green colour, aluminosugilite from the Cerchiara mine is pinkish-purple with pale purple to white streak and a vitreous lustre. It has a Mohs hardness of 6-6.5. Its cleavage is indistinct, poor on (0001). The density, determined by the floatation method using heavy liquids, is $2.71-2.72 \mathrm{~g} \mathrm{~cm}^{-3}$, which is consistent with the density of $2.73 \mathrm{~g} \mathrm{~cm}^{-3}$ calculated using the empirical formula and unit-cell volume refined from single-crystal X-ray diffraction data. Aluminosugilite is optically uniaxial (-), with $\omega=1.577-1.586$ (avg 1.581) and $\varepsilon=1.575-1.585$ (avg 1.580). The refractive indices were determined using stray preparation of several small crystals in immersion oil after Danhara et al. (1992). The mineral has weak pleochroism. The Gladstone-Dale compatibility index of aluminosugilite $\left(1-\mathrm{K}_{P} / \mathrm{K}_{C}\right)$ calculated with the measured density (avg 

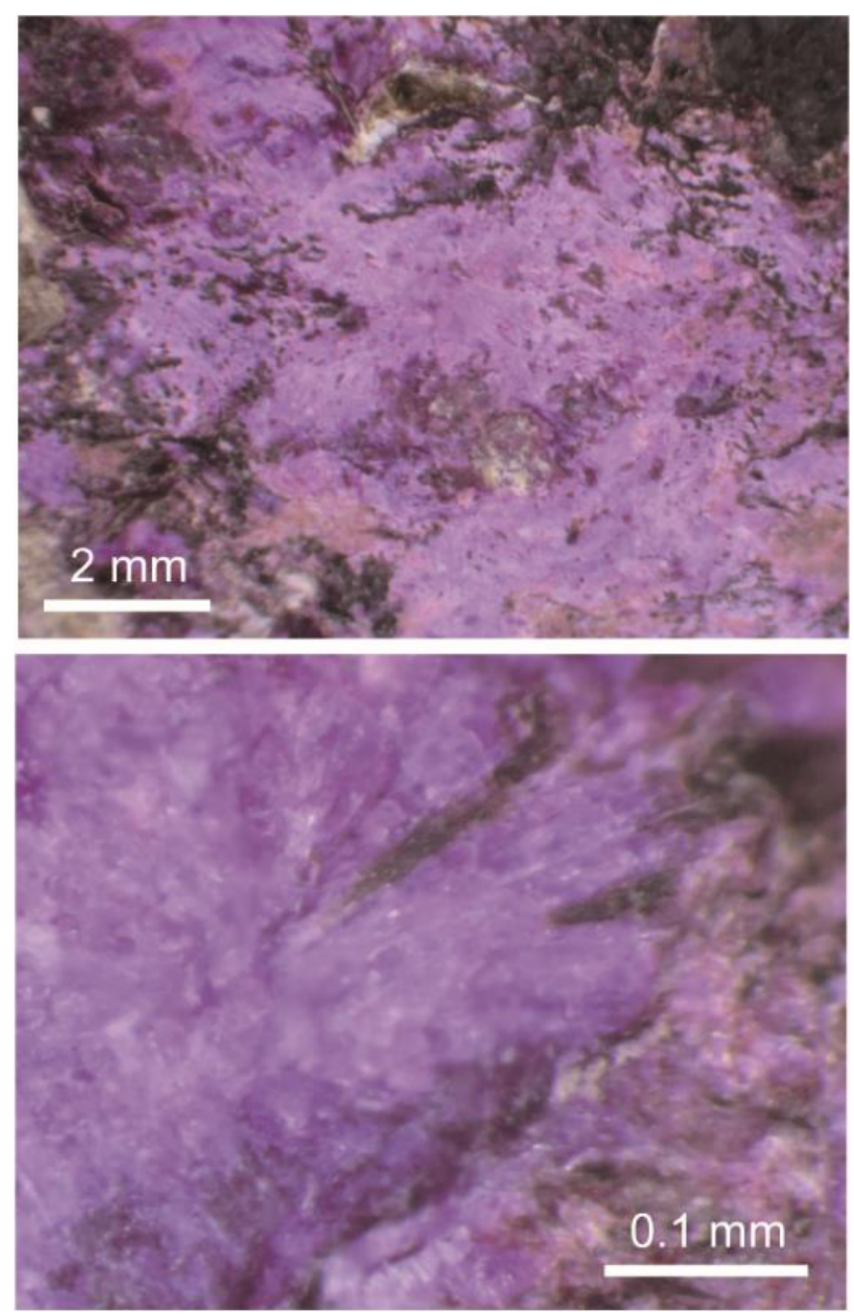

Figure 1. Microphotograph of aluminosugilite.

$2.71 \mathrm{~g} \mathrm{~cm}^{-3}$ ) and average chemical composition listed in Table 1 is +0.003 and falls into the "superior" category according to Mandarino (1981).

The magnetic susceptibility of aluminosugilite from the Cerchiara mine and sugilite from Iwagi Islet were compared by measurements with a Frantz isodynamic separator at room temperature and at a forward slope of $15^{\circ}$ and a slide tilt of $25^{\circ}$. The aluminosugilite and sugilite were attracted to the magnet at 0.9 and $0.6 \mathrm{~A}$, respectively, indicating lower magnetic susceptibility of aluminosugilite than for sugilite. Both specimens did not contain visible impurities. The result is in good agreement with the lower total $\mathrm{Fe}+\mathrm{Mn}$ content of aluminosugilite compared to sugilite.

Both specimens are insoluble in hydrochloric acid $(\mathrm{HCl})$, nitrous acid $\left(\mathrm{HNO}_{3}\right)$ and sulfuric acid $\left(\mathrm{H}_{2} \mathrm{SO}_{4}\right)$, according to chemical tests performed after the method of Jones and Fleming (1965).

\section{Experimental methods}

Chemical analyses of aluminosugilite and sugilite were performed using an electron microprobe analyser (EMPA, JEOL JXA-8230) installed at the Centre for Instrumental Analysis, Yamaguchi University, Japan. The $\mathrm{Li}_{2} \mathrm{O}$ concentration of aluminosugilite was analysed using laser-induced breakdown spectroscopy (LIBS, Applied spectra J200-EC) at Gem Research Japan, Osaka, Japan, whereas the difference to $100 \mathrm{wt} \%$ of the EMPA data in sugilite was assumed to be $\mathrm{Li}_{2} \mathrm{O}$. Operating conditions for EMPA were as follows: accelerating voltage of $15 \mathrm{kV}$, a beam current of $20 \mathrm{nA}$ and a beam diameter of 1-5 $\mu \mathrm{m}$. Wavelength-dispersion spectra were collected using LiF, PET and TAP monochromator crystals to identify interfering elements and locate the best wavelengths for background measurements. The abundances of $\mathrm{Si}, \mathrm{Ti}, \mathrm{Al}, \mathrm{Cr}, \mathrm{V}, \mathrm{Fe}, \mathrm{Mn}, \mathrm{Ni}, \mathrm{Mg}, \mathrm{Ca}, \mathrm{Sr}, \mathrm{Ba}, \mathrm{Na}, \mathrm{K}, \mathrm{P}$, $\mathrm{F}$ and $\mathrm{Cl}$ were measured. Several elements, which are not shown in Table 1, are below the detection limit. The ZAF correction method was applied to all elements. The Li concentration for separated aluminosugilite grains mounted on a glass slide with petropoxy resin was determined using LIBS. The LIBS employed a $266 \mathrm{~nm}$ Nd:YAG laser coupled with an optical emission spectrometer. The employed Li peak was at a wavelength of $670.706 \mathrm{~nm}$. All analyses were carried out under a $\mathrm{He}$ gas flow of $1.0 \mathrm{~L} \mathrm{~min}^{-1}$ with a laser pulse energy of $10 \mathrm{~mJ}$ at $10 \mathrm{~Hz}$ using a laser beam diameter of $35 \mu \mathrm{m}$. The gate delay and pre-ablation times were $0.3 \mu$ s and $0.3 \mathrm{~s}$, respectively, and 25 shots were used for calculations. Emission spectra were collected in the $185.177-1050.782 \mathrm{~nm}$ spectral range covering the main emission lines of major elements (Na, Li, Al, Si, K). The NIST SRM 610 and 612 glasses and a synthetic Li glass were used as calibration standards covering the $\mathrm{Li}_{2} \mathrm{O}$ concentration range between $86.5 \mathrm{ppm}$ (NIST 612 ) and $5 \mathrm{wt} \%$ (Li glass).

$\mathrm{X}$-ray powder diffraction data were collected using a Rigaku MiniFlex automated X-ray powder diffractometer installed at the Centre for Instrumental Analysis, Yamaguchi University. The $\mathrm{Cu}$ X-ray tube for $\mathrm{Cu} K \alpha$ line $(\lambda=1.5418 \AA)$ was operated at $40 \mathrm{kV}$ and $15 \mathrm{~mA}$. Profile was taken over $2 \theta=3-70^{\circ}$ with a step interval of $0.01^{\circ}$.

$\mathrm{X}$-ray diffraction data for a single crystal of aluminosugilite $(0.038 \mathrm{~mm} \times 0.036 \mathrm{~mm} \times 0.028 \mathrm{~mm})$ were collected using a Rigaku MM007 rotating anode generator equipped with VariMax optics, an AFC10 goniometer and HyPix-6000HE detector at Rigaku Corporation, Japan. The crystal was mounted on a glass fibre, and intensity data were measured at room temperature using $\operatorname{Mo} K \alpha$ radiation $(\lambda=0.71073 \AA)$. Preliminary lattice parameters and an orientation matrix were obtained from six sets of frames and refined during the integration process of the intensity data. The diffraction data were processed using CrysAlis $^{\text {Pro }}$ (Rigaku Oxford Diffraction, 2018). An empirical absorption correction using CrysAlis ${ }^{\text {Pro }}$ (Rigaku Oxford Diffraction, 2018) was applied. The diffraction data of 
Table 1. Chemical compositions of aluminosugilite and sugilite, in addition to reference materials.

\begin{tabular}{|c|c|c|c|c|c|c|c|}
\hline \multirow{2}{*}{$\begin{array}{l}\text { Sample } \\
\text { Constituent } \\
\text { (wt \%) }\end{array}$} & \multicolumn{3}{|c|}{ Aluminosugilite $^{\mathrm{a}}$} & \multicolumn{3}{|c|}{ Sugilite $^{b}$} & \multirow[t]{2}{*}{ Reference materials } \\
\hline & Avg & $\begin{array}{l}\text { Range } \\
n=35\end{array}$ & SD & Avg & $\begin{array}{l}\text { Range } \\
n=22\end{array}$ & SD & \\
\hline $\mathrm{SiO}_{2}$ & 72.20 & $70.51-74.23$ & 0.73 & 70.47 & $69.62-71.16$ & 0.32 & $\mathrm{NaAlSi}_{3} \mathrm{O}_{8}$ \\
\hline $\mathrm{TiO}_{2}$ & 0.43 & $0.15-1.15$ & 0.25 & 0.65 & $0.16-1.67$ & 0.39 & $\mathrm{TiO}_{2}$ \\
\hline $\mathrm{Al}_{2} \mathrm{O}_{3}$ & 7.06 & $5.03-9.44$ & 1.22 & 1.81 & $1.48-2.30$ & 0.25 & $\mathrm{Al}_{2} \mathrm{O}_{3}$ \\
\hline $\mathrm{Fe}_{2} \mathrm{O}_{3} \mathrm{c}$ & 1.92 & $0.69-5.60$ & 0.91 & 11.89 & $10.50-12.60$ & 0.55 & $\mathrm{Fe}_{2} \mathrm{O}_{3}$ \\
\hline $\mathrm{Mn}_{2} \mathrm{O}_{3}{ }^{\mathrm{c}}$ & 2.42 & $0.48-4.43$ & 1.31 & 0.02 & $0.00-0.07$ & 0.02 & $\mathrm{MnO}$ \\
\hline $\mathrm{MgO}$ & 0.04 & $0.00-0.65$ & 0.10 & 0.01 & $0.00-0.03$ & 0.01 & $\mathrm{MgO}$ \\
\hline $\mathrm{CaO}$ & 0.01 & $0.00-0.10$ & 0.01 & 0.04 & $0.00-0.31$ & 0.07 & $\mathrm{CaSiO}_{3}$ \\
\hline $\mathrm{Na}_{2} \mathrm{O}$ & 6.17 & $5.99-6.43$ & 0.09 & 5.97 & $5.78-6.11$ & 0.08 & $\mathrm{NaAlSi}_{3} \mathrm{O}_{8}$ \\
\hline $\mathrm{K}_{2} \mathrm{O}$ & 4.68 & $4.39-4.86$ & 0.09 & 4.69 & $4.55-4.76$ & 0.05 & $\mathrm{KAlSi}_{3} \mathrm{O}_{8}$ \\
\hline \multirow[t]{2}{*}{$\mathrm{Li}_{2} \mathrm{O}$} & 4.59 & $4.33-4.70$ & 0.08 & 4.45 & & & - \\
\hline & 99.52 & & & 100.00 & & & \\
\hline Normalized as & $\mathrm{O}=30$ & & & $\mathrm{Si}=12$ & & & \\
\hline $\mathrm{Si}$ & 11.99 & $11.94-12.04$ & 0.02 & 12 & & & \\
\hline $\mathrm{Ti}$ & 0.05 & $0.02-0.14$ & 0.03 & 0.08 & $0.02-0.21$ & 0.05 & \\
\hline $\mathrm{Al}$ & 1.38 & $1.00-1.85$ & 0.23 & 0.36 & $0.30-0.46$ & 0.05 & \\
\hline $\mathrm{Fe}^{3+}$ & 0.24 & $0.09-0.71$ & 0.11 & 1.52 & $1.35-1.61$ & 0.07 & \\
\hline $\mathrm{Mn}^{3+}$ & 0.31 & $0.06-0.57$ & 0.17 & 0.00 & $0.00-0.01$ & 0.00 & \\
\hline $\mathrm{Mg}$ & 0.01 & $0.00-0.16$ & 0.03 & 0.00 & $0.00-0.01$ & 0.00 & \\
\hline $\mathrm{Ca}$ & 0.00 & $0.00-0.02$ & 0.00 & 0.01 & $0.00-0.06$ & 0.01 & \\
\hline $\mathrm{Na}$ & 1.99 & $1.94-2.03$ & 0.02 & 1.97 & $1.90-2.02$ & 0.03 & \\
\hline K & 0.99 & $0.93-1.03$ & 0.02 & 1.02 & $0.99-1.03$ & 0.01 & \\
\hline $\mathrm{Li}$ & 3.06 & $2.94-3.14$ & 0.06 & 3.05 & & & \\
\hline Total & 20.02 & & & 20.02 & & & \\
\hline
\end{tabular}

${ }^{\mathrm{a}} \mathrm{Li}_{2} \mathrm{O}$ content was analysed by LIBS (number of analytical points $=48$ ). Si content obtained by EMPA was used as an internal standard to estimate the Li content. ${ }^{b}$ Difference of total oxide wt $\%$ from 100 wt $\%$ was assumed to be $\mathrm{Li}_{2} \mathrm{O}_{\text {content. }}{ }^{\mathrm{c}} \mathrm{Fe}$ as $\mathrm{Fe}_{2} \mathrm{O}_{3}$ and $\mathrm{Mn}$ as $\mathrm{Mn}_{2} \mathrm{O}_{3}$.

sugilite $(0.03 \mathrm{~mm} \times 0.04 \mathrm{~mm} \times 0.04 \mathrm{~mm})$ were collected at room temperature with graphite-monochromated $\mathrm{Mo} K \alpha \mathrm{X}$ radiation using a Bruker SMART APEX II CCD diffractometer installed at Shimane University, Japan. Preliminary lattice parameters and an orientation matrix were obtained from 12 sets of frames and refined during the integration process of the intensity data. Diffraction data were collected with $\omega$ scans with different $\varphi$ settings ( $\varphi-\omega$ scan) (Bruker, 1999). Data were processed using SAINT (Bruker, 1999). An empirical absorption correction using SADABS (Sheldrick, 1996) was applied. The quality of the data obtained from the Iwagi sugilite was low $\left(R_{\mathrm{int}}=11 \%\right)$ because only a crystal of low quality due to metasomatic origin was available. For both samples, structural refinements were performed using SHELXL-97 (Sheldrick, 2008). Scattering factors for neutral atoms were employed. The reflection statistics and systematic absences were consistent with space groups $P 6 / m c c$. The site occupancies of the $C, T 1$ and $T 2$ sites were refined with $\mathrm{K}, \mathrm{Si}$ and $\mathrm{Li}$ without restraints in our preliminary refinements, respectively. They turned out to be fully occupied within standard deviation in both specimens. Thus, the site occupancies at the $C, T 1$ and $T 2$ sites were fixed as $1.0 \mathrm{~K}$,
1.0 $\mathrm{Si}$ and $1.0 \mathrm{Li}$, respectively. The $A$ site was refined with $\mathrm{Al}$ and $\mathrm{Fe}$ scattering factors. $\mathrm{Fe}, \mathrm{Mn}$ and Ti cannot be distinguished due to their similar atomic-scattering factors. Thus, the $\mathrm{Fe}$ occupation at the $A$ site actually represents $\Sigma(\mathrm{Fe}+$ $\mathrm{Mn})$ for aluminosugilite and $\Sigma(\mathrm{Fe}+\mathrm{Ti})$ for sugilite. In case that $\mathrm{Na}$ at the $B$ site was refined with $(x, y, z)=(1 / 2,2 / 3,0)$ (site symmetry $\overline{6}$ ), an unreasonably large displacement parameter elongated along the $c$ axis was obtained. An additional degree of freedom, $z$ parameter for $\mathrm{Na}$, leads to more reasonable displacement parameters. It is suggested that $\mathrm{Na}$ in this structure is disordered at $1 / 2,2 / 3,0.008(6)$ for aluminosugilite and $1 / 2,2 / 3,0.012(4)$ for sugilite (site symmetry 3), the so-called $B^{\prime}$ site (Abraham et al., 1983). The Na site has distorted 9-fold coordination. A similar coordination of Na was found for sugilite by Armbruster and Oberhänsli (1988). The site occupancy at the $B^{\prime}$ site was $48(2) \%$ of $\mathrm{Na}$ indicating full occupancy within standard deviation. Thus, the value was fixed to $0.5 \mathrm{Na}$, the maximum crystallographic occupancy for this split site. 


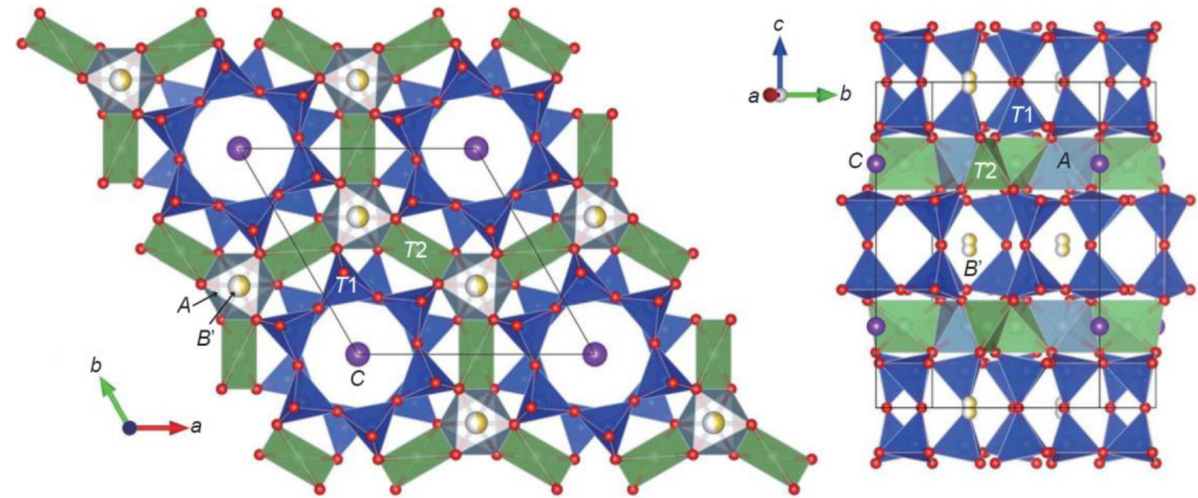

Figure 2. Crystal structure of aluminosugilite drawn with VESTA3 (Momma and Izumi, 2011). The $A$ octahedra are occupied by octahedral trivalent cations, such as $\mathrm{Al}, \mathrm{Fe}^{3+}$ and $\mathrm{Mn}^{3+}$. The $B^{\prime}$ and $C$ sites are occupied by $\mathrm{Na}$ and $\mathrm{K}$, respectively. The $T 1$ tetrahedra consist of double-ring units. The large $T 2$ tetrahedra centred by $\mathrm{Li}$ are strongly angularly distorted. The $B^{\prime}$ site is located at $1 / 3,2 / 3, z$.

\section{Chemical data}

Chemical compositions of aluminosugilite and sugilite, in addition to probe standards, are listed in Table 1. Although each crystal is relatively homogeneous in general, some crystals show the chemical variation characterized by $\mathrm{Al} \leftrightarrow \mathrm{Fe}^{3+}$ and/or $\mathrm{Al} \leftrightarrow \mathrm{Mn}^{3+}$ substitutions. The $\mathrm{Fe}_{2} \mathrm{O}_{3}$ and $\mathrm{Mn}_{2} \mathrm{O}_{3}$ contents attain up to $5.60 \mathrm{wt} \%$ and $4.43 \mathrm{wt} \%$, respectively. Even in such $\mathrm{Fe}^{3+}$ - and/or $\mathrm{Mn}^{3+}$-enriched parts, aluminium ions are still dominant among the octahedral cations. Based on the structural analysis, there is no evidence of an $\mathrm{OH}$ group or $\mathrm{H}_{2} \mathrm{O}$ in the crystal structure of aluminosugilite. The empirical formula of aluminosugilite calculated on the basis of $\mathrm{O}=30$ using the result obtained by EMPA and LIBS (Table 1) is as follows: $\mathrm{K}_{0.99} \mathrm{Na}_{1.99}\left(\mathrm{Al}_{1.38} \mathrm{Mn}_{0.31}^{3+} \mathrm{Fe}_{0.24}^{3+} \mathrm{Ti}_{0.05} \mathrm{Mg}_{0.01}\right)_{\Sigma 1.99} \mathrm{Li}_{3.06}$ $\mathrm{Si}_{11.99} \mathrm{O}_{30}$. The ideal formula is $\mathrm{KNa}_{2} \mathrm{Al}_{2} \mathrm{Li}_{3} \mathrm{Si}_{12} \mathrm{O}_{30}$, which requires (in wt \%) $73.81 \mathrm{SiO}_{2}, 10.44 \mathrm{Al}_{2} \mathrm{O}_{3}, 6.34 \mathrm{Na}_{2} \mathrm{O}, 4.82$ $\mathrm{K}_{2} \mathrm{O}$ and $4.59 \mathrm{Li}_{2} \mathrm{O}$, total $100 \mathrm{wt} \%$. Al- and Mn-rich sugilite has been also reported from the Furumiya mine, Ehime, Japan (Hirowatari and Fukuoka, 1989). Their chemical compositions possibly correspond to aluminosugilite and "manganisugilite" based on the ratios of the $A$ site cations such as $\mathrm{Al}, \mathrm{Fe}^{3+}$ and $\mathrm{Mn}^{3+}$. The $\mathrm{Al}_{2} \mathrm{O}_{3}$ and $\mathrm{Mn}_{2} \mathrm{O}_{3}$ contents in Furumiya sugilite reach $5.364 \mathrm{wt} \%$ and $7.84 \mathrm{wt} \%$, respectively.

Sugilite from Iwagi Islet is rich in $\mathrm{Fe}$ and poor in Al. The $\mathrm{Mn}_{2} \mathrm{O}_{3}$ content is negligible. According to the average composition (Table 1), the chemical formula is $\mathrm{K}_{1.02}\left(\mathrm{Na}_{1.97} \mathrm{Ca}_{0.01}\right)_{\Sigma 1.98}\left(\mathrm{Fe}_{1.52}^{3+} \mathrm{Al}_{0.36} \mathrm{Ti}_{0.08}\right)_{\Sigma 1.98} \mathrm{Li}_{3.05} \mathrm{Si}_{12}$ $\mathrm{O}_{30}$. Although Kato et al. (1976) suggested that $\mathrm{Na}$ shared the $B$ site with $\mathrm{H}_{2} \mathrm{O}$ in the Iwagi sugilite, our preliminary refinement indicates that the $B^{\prime}$ site is fully occupied by $\mathrm{Na}$ within standard deviation and the presence of $\mathrm{H}_{2} \mathrm{O}$ was not supported by the result of chemical analysis. Furthermore, the DTA-TGA analysis of sugilite from the Wessel mine,
South Africa, by Dunn et al. (1980) did not indicate the presence of volatiles.

\section{X-ray crystallography and crystal-structure determination}

The observed and calculated X-ray powder patterns of aluminosugilite are listed in Table S2 in the Supplement. The calculated pattern was obtained based on the result of singlecrystal analysis mentioned below. The cell parameters determined from powder data are $a=9.954(7) \AA, c=13.95(4) \AA$ and $V=1197(4) \AA^{3}$, which is slightly smaller than those obtained from $X$-ray single-crystal method.

Crystallographic data of aluminosugilite and sugilite are summarized in Table 2. The crystal structure of aluminosugilite is shown in Fig. 2. Refinements of the structure converged to $R_{1}=2.17 \%$ for aluminosugilite and $3.32 \%$ for sugilite. The determined cell parameters are $a=$ 9.9830(4) $\AA, c=13.9667(5) \AA$ and $V=1205.45(7) \AA^{3}$ for aluminosugilite, and $a=10.0248(7) \AA, c=14.0310(7) \AA$ and $V=1221.15(2) \AA^{3}$ for sugilite. The refined site occupancies, atomic coordinates and anisotropic displacement parameters are listed in Table 3, selected interatomic distances and angles in Table 4. Based on the refined site occupancies, the structural formula of aluminosugilite is represented as ${ }^{C} \mathrm{~K}^{B} \mathrm{Na}_{2}^{A}\left(\mathrm{Al}_{1.26(1)} \mathrm{Me}_{0.74}^{3+}\right)_{\Sigma 2.00}^{T 2} \mathrm{Li}_{3}^{T l} \mathrm{Si}_{12} \mathrm{O}_{30}$, where $\mathrm{Me}^{3+}=$ $\mathrm{Mn}^{3+}+\mathrm{Fe}^{3+}$. The $A$ site is predominantly occupied by Al. Based on the $\mathrm{Mn}: \mathrm{Fe}$ ratio obtained by EMPA, $56: 44$, the site occupancy of the $A$ site in aluminosugilite is assumed to be $\mathrm{Al}_{0.629(6)} \mathrm{Mn}_{0.21}^{3+} \mathrm{Fe}_{0.16}^{3+}$. On the other hand, $\mathrm{Fe}$ dominates the $A$ site in sugilite. The structural formula of the Iwagi sugilite is ${ }^{C} \mathrm{~K}^{B} \mathrm{Na}_{2}^{A}\left(\mathrm{Fe}_{1.47(2)}^{3+} \mathrm{Al}_{0.53}\right)_{\Sigma 2.00}^{T 2} \mathrm{Li}_{3}^{T l} \mathrm{Si}_{12} \mathrm{O}_{30}$. Trace amount of Ti may be present with $\mathrm{Fe}$ on a basis of chemical analysis (Table 1). The cation assignments in the present study are similar to those suggested for the Wessels mine sugilite by Armbruster and Oberhänsli (1988). On the other hand, Kato et al. (1976) reported that the cation distributions 
Table 2. Experimental details of the single-crystal X-ray diffraction analysis of aluminosugilite and sugilite crystals.

\begin{tabular}{|c|c|c|c|}
\hline \multicolumn{2}{|l|}{ Sample } & Aluminosugilite & Sugilite \\
\hline \multicolumn{2}{|l|}{ Space group } & $P 6 / m c c$ & \\
\hline \multicolumn{2}{|c|}{ Crystal size (mm) } & $0.038 \times 0.036 \times 0.028$ & $0.03 \times 0.04 \times 0.04$ \\
\hline \multirow{3}{*}{ Cell parameters } & $a(\AA)$ & $9.9830(4)$ & $10.0248(7)$ \\
\hline & $c(\AA)$ & $13.9667(5)$ & $14.0310(7)$ \\
\hline & $V\left(\AA^{3}\right)$ & $1205.45(1)$ & $1221.15(2)$ \\
\hline \multicolumn{2}{|l|}{$D_{\text {calc. }}\left(\mathrm{g} \mathrm{cm}^{-3}\right)$} & 2.73 & 2.77 \\
\hline \multicolumn{2}{|l|}{ Radiation } & $\operatorname{Mo} K \alpha(\lambda=0.71073 \AA)$ & \\
\hline \multicolumn{2}{|l|}{ Monochromator } & VariMax optics & Graphite \\
\hline \multicolumn{2}{|l|}{ Diffractometer } & RIGAKU HyPix-6000HE & Bruker APEXII CCD \\
\hline \multicolumn{2}{|c|}{ Scan type } & $\omega$ scan & $\phi-\omega$ scan (Bruker, 1999) \\
\hline \multicolumn{2}{|c|}{ Absorption correction } & CrysAlis ${ }^{\text {Pro }}$ (Rigaku Oxford Diffraction, 2018) & SADABS (Sheldrick, 1996) \\
\hline \multicolumn{2}{|c|}{$\theta_{\min }\left({ }^{\circ}\right)$} & 2.4 & 2.3 \\
\hline \multicolumn{2}{|l|}{$\theta_{\max }\left({ }^{\circ}\right)$} & 29.5 & 25.4 \\
\hline \multicolumn{2}{|c|}{$\mu\left(\mathrm{mm}^{-1}\right)$} & 1.34 & 1.83 \\
\hline \multicolumn{2}{|c|}{ Collected reflections } & 8821 & 6453 \\
\hline \multicolumn{2}{|c|}{ Unique reflections } & 590 & 402 \\
\hline \multicolumn{2}{|c|}{$R_{\text {int }}(\%)$} & 2.43 & 11.00 \\
\hline \multicolumn{2}{|l|}{$R_{\sigma}(\%)$} & 1.27 & 4.39 \\
\hline \multicolumn{2}{|c|}{ Index limits } & $-10 \leq h \leq 12,-13 \leq k \leq 9,-19 \leq l \leq 17$ & $-11 \leq h \leq 12,-12 \leq k \leq 11,-16 \leq l \leq 15$ \\
\hline \multicolumn{2}{|c|}{ Refinement on $F^{2}$ using } & 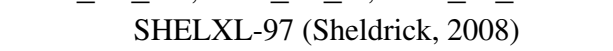 & \\
\hline \multicolumn{2}{|c|}{$R_{1}(\%)$} & 2.17 & 3.32 \\
\hline \multicolumn{2}{|c|}{$w R_{2}(\%)$} & 5.99 & 7.32 \\
\hline \multicolumn{2}{|c|}{ No. of parameters } & 45 & 45 \\
\hline \multicolumn{2}{|c|}{ Weighting scheme* } & $w=1 /\left[\sigma^{2}\left(F_{o}^{2}\right)+(0.0252 P)^{2}\right]+1.83 P$ & $w=1 /\left[\sigma^{2}\left(F_{o}^{2}\right)+(0.0270 P)^{2}+3.24 P\right]$ \\
\hline \multicolumn{2}{|c|}{$\Delta \rho_{\max }\left(e \AA^{-3}\right)$} & 0.35 at $0.74 \AA$ from $\mathrm{O} 2$ & 0.41 at $0.61 \AA$ from $\mathrm{O} 2$ \\
\hline \multicolumn{2}{|l|}{$\Delta \rho_{\min }\left(e \AA^{-3}\right)$} & -0.46 at $0.61 \AA$ from $B$ & -0.41 at $3.19 \AA$ from $\mathrm{O} 2$ \\
\hline
\end{tabular}

* The function of the weighting scheme is $w=1 /\left(\sigma^{2}\left(F_{o}^{2}\right)+(a \cdot P)^{2}+b \cdot P\right)$, where $P=\left(\operatorname{Max}\left(F_{o}^{2}\right)+2 F_{c}^{2}\right) / 3$, and the parameters $a$ and $b$ are chosen to minimize the differences in the variances for reflections in different ranges of intensity and diffraction angle.

of $T 2$ and $A$ in Iwagi sugilite were $\left(\mathrm{Li}_{2.12} \mathrm{Al}_{0.59} \mathrm{Fe}_{0.29}^{3+}\right)$ and $\left(\mathrm{Fe}_{1.32}^{3+} \mathrm{Na}_{0.59} \mathrm{Ti}_{0.06} \mathrm{Fe}_{0.03}^{2+}\right)$, respectively. At least, the number of electrons at each site obtained in the present study cannot support their cation assignments. Armbruster and Oberhänsli (1988) pointed out that the overestimated scattering power of the cations at $T 2$ and erroneous wet-chemical analyses possibly led to the questionable cation assignments reported in Kato et al. (1976).

As mentioned above, the $A$ site in aluminosugilite is predominantly occupied by the smaller $\mathrm{Al}$ ions $(0.535 \AA$ : Shannon, 1976), whereas in sugilite the larger $\mathrm{Fe}^{3+}$ ions $(0.645 \AA)$ prevail. The variation of the $A-\mathrm{O} 3$ distance, $1.940 \AA$ in aluminosugilite (this study) and 1.972-1.981 $\AA$ in sugilite (this study; Armbruster and Oberhänsli, 1988), is governed by the cationic substitution at the $A$ site. Isotropic expansion due to $\mathrm{Fe}^{3+}$ substitution for $\mathrm{Al}$ lengthened the $a$ and $c$ dimensions of sugilite compared to aluminosugilite. In general, the $a$ and $c$ dimensions of the milarite-group minerals are known as ca. 10 and $14 \AA$, respectively (see Table 6 in Armbruster and Oberhänsli, 1988). After Armbruster and Oberhänsli (1988), the length of $a$ dimension varies with that of the shared edge between the $T 2 \mathrm{O}_{4}$-tetrahedra and $A \mathrm{O}_{6}$ octahedra. The oxygen coordination of $\mathrm{Li}$ is known to vary from 3 to 8 . After Wenger and Armbruster (1991), tetrahedral coordination is preferred, and ${ }^{\mathrm{IV}}<\mathrm{Li}-\mathrm{O}>$ is estimated as $1.96(3) \AA$ based on the simplified potential energy. In fact, the estimated $<\mathrm{Li}-$ $\mathrm{O}>$ distance corresponds to that observed in aluminosugilite and sugilite (Table 4).

In sugilite structures, the strongly angularly distorted $T 2(\mathrm{Li}) \mathrm{O}_{4}$ tetrahedron is connect to the fairly regular $A \mathrm{O}_{6}$ octahedron. The shorter $\mathrm{O} 3-\mathrm{O} 3$ edges may lead to the greater bond variance of the $T 2 \mathrm{O}_{4}$ tetrahedron: 545.8 in aluminosugilite and 488-502 in sugilite according to Baur (1974). The $T 2$ tetrahedron occupied by $\mathrm{Li}$ in sugilites is relatively large compared to that occupied by $\mathrm{Al}$, as exemplified by osumilite (ionic radius of ${ }^{\mathrm{IV}} \mathrm{Li}^{+}=0.59 \AA$ and ${ }^{\mathrm{VI}} \mathrm{Al}=0.39 \AA$; Shannon, 1976). While the $T 2-\mathrm{O} 3$ distance in sugilite is $1.97 \AA$, that in osumilite is approximately $1.63 \AA$. Although the $T 2 \mathrm{O}_{4}$ tetrahedron in osumilite is less distorted and its bond variance is much smaller than that of sugilite (238.6 in osumilite; Winter et al., 1995), such a small less-distorted $T 2$ site compresses the edge-shared $A \mathrm{O}_{6}$ octahedron (Armbruster and Oberhänsli, 1988). It makes the $c$ dimension 
Table 3. Refined atomic coordinates, displacement parameters, and site occupancies of aluminosugilite and sugilite.

\begin{tabular}{|c|c|c|c|c|c|}
\hline Sample & Aluminosugilite & Sugilite & & Aluminosugilite & Sugilite \\
\hline$A$ & $\mathrm{Al}_{0.629(6)} \mathrm{Fe}_{0.371} *$ & $\mathrm{Fe}_{0.735(12)} \mathrm{Al}_{0.265} *$ & $B^{\prime}$ & $\mathrm{Na}_{0.5}$ & $\mathrm{Na}_{0.5}$ \\
\hline$x$ & $1 / 3$ & $1 / 3$ & $x$ & $1 / 3$ & $1 / 3$ \\
\hline$y$ & $2 / 3$ & $2 / 3$ & $y$ & $2 / 3$ & $2 / 3$ \\
\hline$z$ & $1 / 4$ & $1 / 4$ & $z$ & $0.008(6)$ & $0.012(4)$ \\
\hline$U^{\text {eq }}$ & $0.0057(3)$ & $0.0051(6)$ & $U^{\mathrm{eq}}$ & $0.035(8)$ & $0.026(8)$ \\
\hline$U^{11}$ & $0.0054(3)$ & $0.0044(7)$ & $U^{11}$ & $0.0209(7)$ & $0.0205(17)$ \\
\hline$U^{22}$ & $0.0054(3)$ & $0.0044(7)$ & $U^{22}$ & $0.0209(7)$ & $0.0205(17)$ \\
\hline$U^{33}$ & $0.0064(4)$ & $0.0062(9)$ & $U^{33}$ & $0.06(2)$ & $0.04(2)$ \\
\hline$U^{12}$ & $0.00268(15)$ & $0.0022(3)$ & $U^{12}$ & $0.0105(3)$ & $0.0103(8)$ \\
\hline C & $\mathrm{K}_{1.0}$ & $\mathrm{~K}_{1.0}$ & $\mathrm{O} 1$ & & \\
\hline$x$ & 0 & 0 & $x$ & $0.1400(2)$ & $0.1386(5)$ \\
\hline$y$ & 0 & 0 & $y$ & $0.3987(2)$ & $0.3976(5)$ \\
\hline$z$ & $1 / 4$ & $1 / 4$ & $z$ & 0 & 0 \\
\hline$U^{\text {eq }}$ & $0.0175(3)$ & $0.0202(9)$ & $U^{\text {eq }}$ & $0.0165(4)$ & $0.0164(10)$ \\
\hline$U^{11}$ & $0.0162(4)$ & $0.0181(13)$ & $U^{11}$ & $0.0205(10)$ & $0.020(3)$ \\
\hline$U^{22}$ & $0.0162(4)$ & $0.0181(13)$ & $U^{22}$ & $0.0185(9)$ & $0.016(2)$ \\
\hline$U^{33}$ & $0.0201(6)$ & $0.024(2)$ & $U^{33}$ & $0.0083(7)$ & $0.010(2)$ \\
\hline$U^{12}$ & $0.0081(2)$ & $0.0091(6)$ & $U^{12}$ & $0.0081(8)$ & $0.007(2)$ \\
\hline$T 1$ & $\mathrm{Si}_{1.0}$ & $\mathrm{Si}_{1.0}$ & $\mathrm{O} 2$ & & \\
\hline$x$ & $0.23601(5)$ & $0.23658(14)$ & $x$ & $0.22500(15)$ & $0.2224(3)$ \\
\hline$y$ & $0.35791(5)$ & $0.35605(13)$ & $y$ & $0.27827(15)$ & $0.2770(3)$ \\
\hline$z$ & $0.38651(3)$ & $0.38701(8)$ & $z$ & $0.13799(9)$ & $0.13742(19)$ \\
\hline$U^{\text {eq }}$ & $0.00726(14)$ & $0.0081(3)$ & $U^{\mathrm{eq}}$ & $0.0143(3)$ & $0.0142(8)$ \\
\hline$U^{11}$ & $0.0070(2)$ & $0.0084(7)$ & $U^{11}$ & $0.0134(6)$ & $0.0130(16)$ \\
\hline$U^{22}$ & $0.0077(2)$ & $0.0084(6)$ & $U^{22}$ & $0.0156(6)$ & $0.0147(17)$ \\
\hline$U^{33}$ & $0.0074(2)$ & $0.0082(6)$ & $U^{33}$ & $0.0188(6)$ & $0.0184(16)$ \\
\hline$U^{23}$ & $0.00043(15)$ & $0.0003(5)$ & $U^{23}$ & $-0.0005(5)$ & $0.0021(14)$ \\
\hline$U^{13}$ & $0.00035(15)$ & $0.0000(5)$ & $U^{13}$ & $-0.0001(5)$ & $0.0008(14)$ \\
\hline$U^{12}$ & $0.00394(17)$ & $0.0048(5)$ & $U^{12}$ & $0.0109(5)$ & $0.0094(14)$ \\
\hline$T 2$ & $\mathrm{Li}_{1.0}$ & $\mathrm{Li}_{1.0}$ & $\mathrm{O} 3$ & & \\
\hline$x$ & $1 / 2$ & $1 / 2$ & $x$ & $0.16906(14)$ & $0.1659(3)$ \\
\hline$y$ & $1 / 2$ & $1 / 2$ & $y$ & $0.51105(13)$ & $0.5084(3)$ \\
\hline$z$ & $1 / 4$ & $1 / 4$ & $z$ & $0.17136(8)$ & $0.1702(2)$ \\
\hline$U^{\mathrm{eq}}$ & $0.0156(11)$ & $0.012(3)$ & $U^{\mathrm{eq}}$ & $0.0114(3)$ & $0.0120(7)$ \\
\hline$U^{11}$ & $0.018(2)$ & $0.009(5)$ & $U^{11}$ & $0.0111(6)$ & $0.0104(16)$ \\
\hline$U^{22}$ & $0.018(2)$ & $0.009(5)$ & $U^{22}$ & $0.0090(5)$ & $0.0112(16)$ \\
\hline$U^{33}$ & $0.015(2)$ & $0.018(7)$ & $U^{33}$ & $0.0138(5)$ & $0.0148(15)$ \\
\hline \multirow[t]{3}{*}{$U^{12}$} & $0.012(3)$ & $0.004(6)$ & $U^{23}$ & $-0.0026(5)$ & $-0.0030(14)$ \\
\hline & & & $U^{13}$ & $-0.0006(5)$ & $-0.0010(12)$ \\
\hline & & & $U^{12}$ & $0.0048(5)$ & $0.0056(13)$ \\
\hline
\end{tabular}

${ }^{*} \mathrm{Fe}$ represents $\Sigma(\mathrm{Fe}+\mathrm{Mn})$ in aluminosugilite and $\Sigma(\mathrm{Fe}+\mathrm{Ti})$ in sugilite.

shorter. The dominant $T 2$ and $A$ cations thus govern the variation of $a$ and $c$ dimensions. Although the dominant influence of the $C-\mathrm{O}$ distance on the $c$ dimension was also pointed out (Armbruster and Oberhänsli, 1988), the $C$ site is fully occupied by potassium and shows no compositional variation in the case of aluminosugilite and sugilite.

\section{Recommended nomenclature of the milarite-group mineral}

The structural formula of milarite-group minerals is represented as ${ }^{\mathrm{VI}} A_{2}^{\mathrm{IX}} B_{2}^{\mathrm{XII}} C^{\mathrm{IV}}(T 2)_{3}^{\mathrm{IV}}(T 1)_{12} \mathrm{O}_{30}$. Heterovalent (coupled) substitutions among the $A, B$ and $T 2$ sites are common in this group, leading to the chemical variability of the group (Table S1). On the other hand, the species only related to the homovalent 
Table 4. Selected interatomic distances $(\AA)$ and angles $\left(^{\circ}\right)$ of aluminosugilite and sugilite.

\begin{tabular}{lrr}
\hline Sample & Aluminosugilite & Sugilite \\
\hline$A-\mathrm{O} 3(\times 6)$ & $1.9395(12)$ & $1.981(3)$ \\
\hline$B^{\prime}-\mathrm{O} 1(\times 3)$ & $2.394(5)$ & $2.419(5)$ \\
$B^{\prime}-\mathrm{O} 3(\times 3)$ & $2.78(7)$ & $2.75(4)$ \\
$B^{\prime}-\mathrm{O} 3(\times 3)$ & $2.98(7)$ & $3.03(5)$ \\
\hline$C-\mathrm{O} 2(\times 12)$ & $2.9950(13)$ & $2.997(3)$ \\
\hline$T 1-\mathrm{O} 1$ & $1.6240(6)$ & $1.6260(14)$ \\
$T 1-\mathrm{O} 2$ & $1.6207(13)$ & $1.621(3)$ \\
$T 1-\mathrm{O} 2$ & $1.6172(12)$ & $1.619(3)$ \\
$T 1-\mathrm{O} 3$ & $1.5788(12)$ & $1.575(3)$ \\
$<T 1-\mathrm{O}>$ & 1.6102 & 1.610 \\
$\mathrm{O} 1-T 1-\mathrm{O} 2$ & $108.11(9)$ & $108.0(2)$ \\
$\mathrm{O} 1-T 1-\mathrm{O} 3$ & $108.35(9)$ & $108.0(2)$ \\
$\mathrm{O} 2-T 1-\mathrm{O} 1$ & $110.56(8)$ & $111.0(2)$ \\
$\mathrm{O} 2-T 1-\mathrm{O} 3$ & $111.27(7)$ & $111.6(2)$ \\
$\mathrm{O} 2-T 1-\mathrm{O} 2$ & $104.14(9)$ & $103.7(2)$ \\
$\mathrm{O} 3-T 1-\mathrm{O} 2$ & $114.32(7)$ & $114.5(2)$ \\
\hline$T 2-\mathrm{O} 3(\times 4)$ & $1.9700(12)$ & $1.972(3)$ \\
$\mathrm{O} 3-T 2-\mathrm{O} 3$ & $84.21(7)$ & $86.1(2)$ \\
$\mathrm{O} 3-T 2-\mathrm{O} 3$ & $112.23(7)$ & $110.8(2)$ \\
$\mathrm{O} 3-T 2-\mathrm{O} 3$ & $136.28(7)$ & $135.4(2)$ \\
\hline$T 1-\mathrm{O} 1-T 1$ & $154.85(14)$ & $154.3(3)$ \\
$T 1-\mathrm{O} 2-T 1$ & $152.67(9)$ & $152.4(2)$ \\
$T 1-\mathrm{O} 3-T 2$ & $113.51(7)$ & $114.5(2)$ \\
\hline
\end{tabular}

cationic substitution at the $A$ site are also observed as follows: $\mathrm{Fe}^{2+} \leftrightarrow \mathrm{Mg}$ substitution between osumilite and osumilite-(Mg), $\quad C_{\mathrm{K}^{A}}\left(\mathrm{Fe}^{2+}, \mathrm{Mg}\right)_{2}^{T 2} \mathrm{Al}_{3}^{T 1}\left(\mathrm{Al}_{2} \mathrm{Si}_{10}\right) \mathrm{O}_{30}$ (Miyashiro, 1956; Chukanov et al., 2013), $\mathrm{Zr} \leftrightarrow \mathrm{Sn} \leftrightarrow \mathrm{Ti}$ substitution among sogdianite, brannockite and berezanskite, ${ }^{C} \mathrm{~K}^{A}(\mathrm{Zr}, \mathrm{Sn}, \mathrm{Ti}){ }_{2}^{T 2} \mathrm{Li}_{3}^{T 1} \mathrm{Si}_{12} \mathrm{O}_{30}$ (Dusmatov et al., 1968; White Jr. et al., 1973; Pautov and Agakhanov, 1997), $\mathrm{Mn} \leftrightarrow \mathrm{Ca}$ substitution between dusmatovite and shibkovite, $\quad C_{\mathrm{K}^{B}}(\square \mathrm{K})_{2}^{A}(\mathrm{Mn}, \mathrm{Ca})_{2}^{T 2} \mathrm{Zn}_{3}^{T}{ }^{1} \mathrm{Si}_{12} \mathrm{O}_{30}$ (Pautov et al., 1996, 1998), and milarite and almaru-

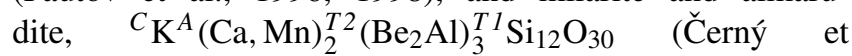
al., 1980; Mihajlović et al., 2004), and $\mathrm{Y} \leftrightarrow \mathrm{Sc}$ substitution between oftedalite and agakhanovite-(Y) ${ }^{C} \mathrm{~K}^{A}[(\mathrm{Sc}, \mathrm{Y}) \mathrm{Ca}]_{2}^{T 2} \mathrm{Be}_{3}^{T 1} \mathrm{Si}_{12} \mathrm{O}_{30}$ (Cooper et al., 2006; Hawthorne et al., 2014) (Table S1). Compositional relation between sugilite and the newly found aluminosugilite reflects homovalent substitution, $\mathrm{Fe}^{3+} \leftrightarrow \mathrm{Al}$, at the $A$ site.

Gagné and Hawthorne (2016) summarized chemical and structural properties of the milarite-type structure and mentioned that "this difference between homovalent and heterovalent substitutions is embedded in the more recent classification/nomenclature scheme for minerals (e.g. arrojadite, Chopin et al., 2006; tourmaline, Henry et al., 2011; amphibole, Hawthorne et al., 2012), where root compositions are assigned a root name and homovalent analogues are named by adding prefixes or suffixes to the appropriate root name". In milarite-group minerals, osumilite-( $\mathrm{Mg})$ has been approved as an independent species (Chukanov et al., 2013). In this case a suffix designation was used to characterize the dominant cation at the $A$ site. However, we would have much preferred using a prefix for a cation of primary importance in double-ring silicates ( $A$ site) following the guideline on the use of prefix in the mineralogical nomenclature of IMA Commission (Hey and Gottardi, 1980). The cations at the $B$ and $C$ channel sites are flexible, and they play a role to maintain charge balance. The $C$ site is generally occupied by $\mathrm{K}$, but there are also species having $\mathrm{Ba}$ or vacancies. The $B$ site may be empty or can be fully occupied by Na or K. Thus, it is suggested to leave the possibility of a suffix for variation of the channel sites, $B$ and $C$. Since the key cation sites to determine the root name have not been defined in milarite group as it stands, it is too premature to re-name existing minerals. On the other hand, giving a totally different name is unnecessary and leads to proliferation of species names. This is particularly true for new species which are only differentiated by the dominant cation at a certain site. Thus, we conclude that if only the $A$ cation in a newly discovered milarite-group mineral is different from an existing species, the addition of a prefix derived from the dominant $A$ cation is reasonable to avoid further confusion. It may be advisable to revive and discuss the nomenclature of milarite-group minerals in the near future.

Data availability. The CIF files can be obtained from the corresponding author.

Supplement. The supplement related to this article is available online at: https://doi.org/10.5194/ejm-32-57-2020-supplement.

Author contributions. MN designed the project. GO and GA performed the field investigation and sample collection. MN performed and validated the analyses by EMPA, X-ray powder diffraction and $\mathrm{X}$-ray single-crystal diffraction using Bruker APEX II. CF performed the analysis by LIBS. TI performed chemical test and the measurement of magnetic susceptibility. TM collected X-ray singlecrystal diffraction data using a Rigaku MM007. MN and TI discussed all results, and MN wrote the paper.

Competing interests. The authors declare that they have no conflict of interest.

Acknowledgements. We thank Roberto Cabella and Gabriella Lucchetti from the University from Genoa, Italy, for their constructive comments on the occurrence of aluminosugilite, Thomas Armbruster for his constructive comments on the nomenclature of 
milarite-group minerals, Yuzuru Maki (Rigaku Corporation) for his arrangement to use RIGAKU HyPix-6000HE, Masahide Akasaka for his permission on the use of Bruker APEX II installed at Shimane University, and Yoji Morifuku for his technical assistance. We also thank the Editor-in-Chief Sergey Krivovichev, Christian L. Lengauer and an anonymous reviewer. One of the authors (Mariko Nagashima) gratefully acknowledge the financial supports of Grants-in-Aid for Scientific Research from the Japan Society for the Promotion of Science, nos. 285800296 and 18K03782.

Financial support. This research has been supported by the Grantsin-Aid for Scientific Research from the Japan Society for the Promotion of Science (grant nos. 285800296 and 18K03782).

Review statement. This paper was edited by Sergey Krivovichev, and reviewed by Christian L. Lengauer and an anonymous reviewer.

\section{References}

Abraham, K., Gebert, W., Medenbach, O., Schreyer, W., and Hentschel, G.: Eifelite, $\mathrm{KNa}_{3} \mathrm{Mg}_{4} \mathrm{Si}_{12} \mathrm{O}_{30}$, a new mineral of the osumilite group with octahedral sodium, Contrib. Mineral. Petr., 82, 252-258, https://doi.org/10.1007/BF01166619, 1983.

Armbruster, T.: Crystal chemistry of double-ring silicates: structure of roedderite at 100 and $30 \mathrm{~K}$, Eur. J. Mineral., 1, 715-718, https://doi.org/10.2138/am-1999-1-210, 1989.

Armbruster, T.: Si, Al ordering in the double-ring silicate armenite, $\mathrm{BaCa}_{2} \mathrm{Al}_{6} \mathrm{Si}_{9} \mathrm{O}_{20} \cdot 2 \mathrm{H}_{2} \mathrm{O}:$ A single-crystal X-ray and ${ }^{29} \mathrm{Si}$ MAS NMR study, Am. Mineral., 84, 92-101, https://doi.org/10.2138/am-1999-1-210, 1999.

Armbruster, T. and Czank, M.: $\mathrm{H}_{2} \mathrm{O}$ ordering and superstructures in armenite $\mathrm{BaCa}_{2} \mathrm{Al}_{6} \mathrm{Si}_{9} \mathrm{O}_{20} \cdot 2 \mathrm{H}_{2} \mathrm{O}$ : A single-crystal X-ray and TEM study, Am. Mineral., 77, 422-430, 1992.

Armbruster, T. and Oberhänsli, R.: Crystal chemistry of double-ring silicates: Structures of sugilite and brannockite, Am. Mineral., 73, 595-600, 1988.

Baur, H.: The geometry of polyhedral distortions. Predictive relationships for the phosphate group, Acta Crystallogr., B30, 11951215, https://doi.org/10.1107/S0567740874004560, 1974.

Bruker: SMART and SAINT-Plus, Versions 6.01, Bruker AXS Inc., Madison, Wisconsin, USA, 1999.

Cabella, R., Lucchetti, G., and Palenzona, A.: Al-rich, Fe-poor manganoan sugilite in a pectolite-bearing assemblage from Cerchiara Mine (Northern Apennines, Italy), Neues Jb. Miner. Monat., 10, 443-448, 1990.

Cabella, R., Lucchetti, G., and Marescotti, P.: Mn-ores from Eastern Ligurian ophiolitic sequences ("Diaspri di Monte Alpe Formation", Northern Apennines, Italy), Trends in Mineralogy, 2, $1-17,1998$.

Černý, P., Hawthorne, F. C., and Jarosewich, E.: Crystal chemistry of milarite, Can. Mineral., 18, 41-57, 1980.

Chopin, C., Oberti, R., and Cámara, F.: The arrojadite enigma: II. Compositional space, new members, and nomenclature of the group, Am. Mineral., 91, 1260-1270, https://doi.org/10.2138/am.2006.2190, 2006.
Chukanov, N. V., Pekov, I. V., Rastsvetaeva, R. K., Aksenov, S. M., Belakovskiy, D. I., Van, K. V., Schüller, W., and Ternes, B.: Osumilite-(Mg): Validation as a mineral species and new data, Geol. Ore Deposit., 55, 587-593, https://doi.org/10.1134/S1075701513070064, 2013.

Cooper, M. A., Hawthorne, F. C., Ball, N. A., Černý, P., and Kristiansen, R.: Oftedalite, $\left(\mathrm{Sc}, \mathrm{Ca}, \mathrm{Mn}^{2+}\right)_{2} \mathrm{~K}(\mathrm{Be}, \mathrm{Al})_{3} \mathrm{~S}_{12} \mathrm{O}_{30}$, a new member of the milarite group from the Heftetjern pegmatite, Tørdal, Norway: description and crystal structure, Can. Mineral., 44, 943-949, https://doi.org/10.2113/gscanmin.44.4.943, 2006.

Danhara, T., Yamashita, T., Iwano, H., and Kasuya, M.: An improved system for measuring refractive index using the thermal immersion method, Quartern. Int., 13/14, 89-91, https://doi.org/10.1016/1040-6182(92)90013-R, 1992.

Dunn, P. J., Brummer, J. J., and Belsky, H.: Sugilite, a second occurrence: Wessels mine, Kalahari manganese field, Republic of South Africa, Can. Mineral., 18, 37-39, 1980.

Dusmatov, V. D., Efimova, A. F., Kataeva, Z. T., Khoroshilova, L. A., and Yanulov, K. P.: Sogdianite, a new mineral, Dokl. Akad. Nauk SSSR, 182, 1176-1177, 1968.

Forbes, W. C., Baur, W. H., and Kahn, A. A.: Crystal chemistry of milarite-type minerals, Am. Mineral., 57, 463-472, 1972.

Gagné, O. and Hawthorne, F. C.: Chemographic exploration of the milarite-type structure, Can. Mineral., 54, 1229-1247, https://doi.org/10.3749/canmin.1500088, 2016.

Hawthorne, F. C., Oberti, R., Harlow, G. E., Maresch, W. V., Martin, R. F., Schumacher, J. C., and Welch, M. D.: Nomenclature of the amphibole supergroup, Am. Mineral., 97, 2031-2048, https://doi.org/10.2138/am.2012.4276, 2012.

Hawthorne, F. C., Abdu, Y. A., Ball, N. A., Černý, P., and Kristiansen, R.: Agakhanovite-(Y), ideally (YCa) $\square_{2} \mathrm{KBe}_{3} \mathrm{Si}_{12} \mathrm{O}_{30}$, a new milarite-group mineral from the Heftetjern Pegmatite, Tørdal, Southern Norway: Description and crystal structure, Am. Mineral., 99, 2084-2088, https://doi.org/10.2138/am-20144880, 2014.

Henry, D. J., Novák, M., Hawthorne, F. C., Ertl, A., Dutrow, B. L., Uher, P., and Pezzotta, F.: Nomenclature of the tourmaline super-group minerals, Am. Mineral., 96, 895-913, https://doi.org/10.2138/am.2011.3636, 2011.

Hey, M. H. and Gottardi, G.: On the use of names, prefixes and suffixes, and adjectival modifiers in the mineralogical nomenclature, Can. Mineral., 18, 261-262, 1980.

Hirowatari, F. and Fukuoka, M.: Some Problems of the studies on the manganese minerals in Japan, Journal of the Mineralogical Society of Japan, 18, 347-365, https://doi.org/10.2465/gkk1952.18.347, 1989.

Jones, M. P. and Fleming, M. G.: Identification of mineral grains. Elsevier Publishing Company, Amsterdam, 102 pp., 1965.

Kato, T., Miúra, Y., and Murakami, N.: Crystal structure of sugilite, Mineralogical Journal, 8, 184-192, https://doi.org/10.2465/minerj.8.184, 1976.

Kolitsch, U., Merlino, S., Belmonte, D., Carbone, C., Cabella, R., Lucchetti, G., and Ciriotti, M. E.: Lavinskyite-1 $M$, $\mathrm{K}(\mathrm{LiCu}) \mathrm{Cu}_{6}\left(\mathrm{Si}_{4} \mathrm{O}_{11}\right)_{2}(\mathrm{OH})_{4}$, the monoclinic MDO equivalent of lavinskyite-2O (formerly lavinskyite), from the Cerchiara manganese mine, Liguria, Italy, Eur. J. Mineral., 30, 811-820, https://doi.org/10.1127/ejm/2018/0030-2731, 2018.

Lepore, G. O., Bindi, L., Zanetti, A., Ciriotti, M. E., Medenbach, O., and Bonazzi, P.: Balestraite, $\mathrm{KLi}_{2} \mathrm{VSi}_{4} \mathrm{O}_{10} \mathrm{O}_{2}$, the first member 
of the mica group with octahedral $\mathrm{V}^{5+}$, Am. Mineral., 100, 608614, https://doi.org/10.2138/am-2015-4972, 2015.

Lucchetti, G., Cortesogno, L., and Palenzona, A.: Low-temperature metamorphic mineral assemblages in $\mathrm{Mn}$-Fe ores from Cerchiara mine (northern Apennine, Italy), Neues Jb. Miner. Monat., 8, 367-383, 1988.

Mandarino, J. A.: The Gladstone-Dale relationship: Part IV. The compatibility concept and its application, Can. Mineral., 19, 441-450, 1981.

Mihajlović, T., Lengauer, C. L., Ntaflos, T., Kolitsch, U., and Tillmanns, E.: Two new minerals, rondorfite, $\mathrm{Ca}_{8} \mathrm{Mg}\left[\mathrm{SiO}_{4}\right]_{4} \mathrm{Cl}_{2}$, and almarudite, $\mathrm{K}(\square, \mathrm{Na})_{2}(\mathrm{Mn}, \mathrm{Fe}, \mathrm{Mg})_{2}(\mathrm{Be}, \mathrm{Al})_{3}\left[\mathrm{Si}_{12} \mathrm{O}_{30}\right]$, and a study on iron-rich wadalite, $\mathrm{Ca}_{12}\left[\left(\mathrm{Al}_{8} \mathrm{Si}_{4} \mathrm{Fe}_{2}\right) \mathrm{O}_{32}\right] \mathrm{Cl}_{6}$, from the Bellerberg volcano, Eifel, Germany, Nues Jb. Miner. Abh., 179, 265-294, https://doi.org/10.1127/00777757/2004/0179-0265, 2004.

Miyashiro, A.: Osumilite, a new silicate mineral and its crystal structure, Am. Mineral., 41, 104-116, 1956.

Momma, K. and Izumi, F.: VESTA3 for three-dimensional visualization of crystal, volumetric and morphology data, J. Appl. Crystallogr., 44, 1257-1276, https://doi.org/10.1107/S0021889811038970, 2011.

Murakami, N., Kato, T., Miura, Y., and Hirowatari, F.: Sugilite, a new silicate mineral from Iwagi Islet, Southwest Japan, Mineralogical Journal, 8, 110-121, https://doi.org/10.2465/minerj.8.110, 1976.

Nickel, E. H. and Grice, J. D.: The IMA commission on new minerals and mineral names: Procedures and guidelines on mineral nomenclature, 1998, Miner. Petrol., 64, 237-263, https://doi.org/10.1007/BF01226571, 1998.

Pautov, L. A. and Agakhanov, A. A.: Berezanskite $\mathrm{KLi}_{3} \mathrm{Ti}_{2} \mathrm{Si}_{12} \mathrm{O}_{30}$, a new mineral, Zapiski Vsesoyuznogo Mineralogicheskogo Obshchestva, 126, 75-80, 1997.
Pautov, L. A., Agakhanov, A. A., Sokolova, E. V., and Ignatenko, K. I.: Dusmatovite, a new mineral of milarite group, Vestnik Moskovskogo Universiteta, Seriya 4, Geologicheskaya, N2, 54 60, 1996.

Pautov, L. A., Agakhanov, A. A., and Sokolova, E. V.: Shibkovite, a new mineral of milarite group, Zapiski Vsesoyuznogo Mineralogicheskogo Obshchestva, 127, 89-94, 1998.

Rigaku Oxford Diffraction: CrysAlis ${ }^{\text {Pro }}$ Software system, version 1.171.39.45e, Rigaku Corporation, Oxford, UK, 2018.

Shannon, R. D.: Revised effective ionic radii and systematic studies of interatomic distances in halides and chalcogenides, Acta Crystallogr., A32, 751-767, https://doi.org/10.1107/S0567739476001551, 1976.

Sheldrick, G. M.: SADABS, University of Göttingen, Germany, 1996.

Sheldrick, G. M.: A short history of SHELX, Acta Crystallogr., A64, 112-122, https://doi.org/10.1107/S0108767307043930, 2008.

Wenger, M. and Armbruster, T.: Crystal chemistry of lithium: oxygen coordination and bonding, Eur. J. Mineral., 3, 387-399, https://doi.org/10.1127/ejm/3/2/0387, 1991.

White Jr., J. S., Arem, J. E., Nelen, J. A., Levens, P. B., and Thomssen, R. W.: Brannockite, a new tin material, Miner. Rec., 4, 73-76, 1973.

Winter, W., Armbruster, T., and Lengauer, Ch.: Crystal structure refinement of synthetic osumilite-type phases: $\mathrm{BaMg}_{2} \mathrm{Al}_{6} \mathrm{Si}_{9} \mathrm{O}_{30}$, $\mathrm{SrMg}_{2} \mathrm{Al}_{6} \mathrm{Si}_{9} \mathrm{O}_{30}$ and $\mathrm{Mg}_{2} \mathrm{Al}_{4} \mathrm{Si}_{11} \mathrm{O}_{30}$, Eur. J. Mineral., 7, $277-$ 286, https://doi.org/10.1127/ejm/7/2/0277, 1995. 